\title{
Deep expression scrutiny provides genetic basis of aluminium tolerance in wild (Lens nigrican) and cultivated lentil (Lens culinaris Medik.)
}

Research article

Keywords:

Posted Date: December 9th, 2020

DOl: https://doi.org/10.21203/rs.3.rs-17426/v2

License: (c) (1) This work is licensed under a Creative Commons Attribution 4.0 International License.

Read Full License 


\section{Abstract}

The authors have requested that this preprint be withdrawn due to erroneous posting.

\section{Full Text}

The authors have withdrawn this preprint from Research Square. 